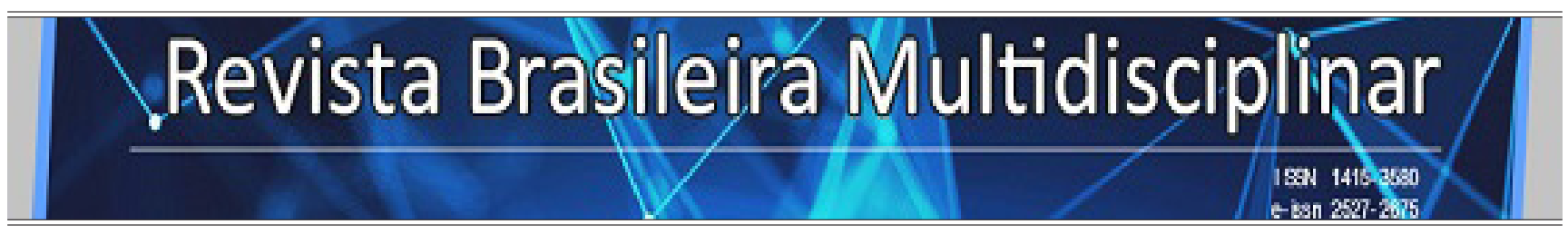

http://revistarebram.com/index.php/revistauniara

\title{
EXPLORING THE STAPHYLOCOCCUS AUREUS IN PATIENTS INFECTED OF THE TERTIARY- CARE UNIVERSITY HOSPITAL: RESULTS OF THE RETROSPECTIVE COHORT STUDY
}

Maria Clara Bisaio Quillici; Claudete Freitas ${ }^{\star}$; Cristiane Silveira de Brito*; Iara Rossi Gonçalves*; Lizandra Ferreira de Almeida e Borges ${ }^{\star}$; Melina Lorraine Ferreira ${ }^{\star}$; Paola Amaral de Campos*; Rosineide Marques Ribas ${ }^{\star}$; Juliana Pena Porto*

${ }^{*}$ Molecular Microbiology Laboratory, Intitute of Biomedical Sciences, Federal University of Uberlândia-MG.

*Autor para correspondência e-mail: mariaclarabq@gmail.com

Palavras-chave

Infecção Hospitalar Staphylococcus Aureus MRSA

Virulência

\section{KEYWORDS}

Cross Infection

Staphylococcus Aureus

MRSA

Virulence

\section{Abstract}

To establish a baseline of knowledge regarding about inappropriate therapy, virulence and resistance in a cohort of patients infected with $S$. aureus. Retrospective cohort study in tertiary-care university hospital was employed to evaluate the risk factors and the impact of inappropriate therapy among patients with Staphylococcus aureus infections, resistance and virulence. To assess the presence of the genes was performed PCR. Patients with MRSA were older and hospitalized 17 days longer than those with MSSA infection, which were in ICU with a bloodstream infection. 50.0\% received inappropriate antibiotic therapy and we found virulence factors associated with MRSA ( $m e c \mathrm{~A}, L u k S$, $f n b \mathrm{~B}$ and $c l f \mathrm{~A}$ genes). These data show that monitoring studies related to Staphylococcus aureus infections remain essential to identify resistance and inform policy on resistance.

EXPLORANDO O STAPHYLOCOCCUS AUREUS EM PACIENTES INFECTADOS EM UM HOPITAL UNIVERSITÁRIO TERCIÁRIO: RESULTADOS DE UM ESTUDO DE COORTE RETROSPECTIVO

Estabelecer uma linha de base de conhecimentos sobre terapia inadequada, virulência e $r$ esistência em uma coorte de pacientes infectados com S. aureus. Estudo de coorte retrospectivo em hospital universitário de atendimento terciário foi empregado para avaliar os fatores de risco e o impacto da terapia inadequada entre pacientes com infecções por Staphylococcus aureus, resistência e virulência. Para avaliar a presença dos genes foi realizado PCR. Pacientes com MRSA eram mais velhos e hospitalizados 17 dias a mais do que aqueles com infecção por MSSA, que estavam em UTI com infecção na corrente sanguínea. 50,0\% receberam antibioticoterapia inadequada e encontramos fatores de virulência associados ao MRSA (genes mecA, $L u k \mathrm{~S}, f n b \mathrm{~B}$ e $c l f \mathrm{~A}$ ). Esses dados mostram que os estudos de vigilância relacionados às infecções por Staphylococcus aureus permanecem essenciais para identificar a resistência e informar as políticas sobre resistência. 


\section{INTRODUCTION}

The epidemiology of Staphylococcus aureus is dynamic and has been presenting significant changes in recent years (OLIVEIRA; FARIA; LEVYAND, et al. 2001; AÑ́́N; RODRÍGUEZ; TINAJAS, et al. 2004; PARKER, 2017; KOECH; COMO-SABETTI; BOXRUDE, 2019). Although Gram-negative bacteria are the most common source of nosocomial infections, $S$. aureus infections are still a substantial source of morbidity and mortality because they have the ability to induce inflammation and are responsible for superficial and invasive infections PELEG; HOOPER, 2010; SCHWEIZER.; EBER; LAXMINARAYAN, et al. 2011).

The treatment of infections caused by this microorganism is complicated by the high prevalence of multidrug-resistant strains, selected by the indiscriminate and inappropriate use of antibiotic, mainly associated with horizontal transfer of genes of resistance (HEGGERNDORNN; GOMES; SILVA, et al. 2016).

S. aureus still presents an arsenal of virulence factors that contribute to its survival and development, and it is responsible for the onset of clinical manifestations and severity of infections RICARDO-CALDERA; BUELVAS-DORIA; ESCOBAR-PÉREZ, et al. 2015). Although resistance plays an important role in the worsening of these infections, the pathogenic capacity of this microorganism is the result of the combined effect of the production of virulence factors, such as enzymes and toxins, and the ability to form biofilm, multiplication and dissemination in tissues and organs, besides its invasive capacity (CHAMBERS; DELEO, 2009; STEFANI; GOGLIO, 2010; BIMANAND, L.; TAHERIKALANI; JALILIAN, et al. 2018).

Reports of methicillin-resistant Staphylococcus aureus (MRSA) emerged in the 1960s, and currently, MRSA isolates are estimated with a prevalence of 25 of $50 \%$ or more in some hospitalization areas (INDRAWATTANA; SUNGKHACHAT; SOOKRUNG, et al. 2013; SANTAJIT; INDRAWATTANA, 2016). In recent years, due to the increased rate of detection of MRSA, empirical antibiotic treatment has become even more difficult, additionally, when the prescription occurs inappropriately, there is an increase in hospital stay, treatment costs and risk of death (PAUL; SHANI; MUCHTAR, et al. 2010; WEISS; FITZGERALD; BALAMUTH, et al. 2014; ZHANG; MICEK; KOLLEF, 2015; LI; LI; ZHANG, et al. 2019).

We aim to establish a baseline of knowledge regarding about inappropriate therapy, virulence and resistance in a cohort of patients infected with $S$. aureus.

\section{MATERIALS AND METHODS}

\section{Patients, SetTings And study design}

The data base at our clinical microbiology laboratory was reviewed to identify patients with Staphylococcus aureus infections from November/2015 to April/2016 at Uberlandia University Hospital (Brazil), a 533-bed tertiary-care university hospital. For comparison between patients with Methicillinresistant Staphylococcus aureus (MRSA) and methicillin-susceptible Staphylococcus aureus (MSSA), only the first episode was analyzed.

A retrospective cohort study was employed to evaluate the risk factors and the impact of inappropriate therapy among patients with Staphylococcus aureus infections. During the surveillance period, 80 episodes of $S$. aureus infection were recovered from 55 patients. The main outcome was in hospital mortality and the procedure also assessed secondary outcomes, including the duration of hospital stays, admission to the Intensive Care Unit (ICU) and the use of central venous catheter and mechanical ventilation.

The data and the samples analyzed in the present study were obtained in accordance with the norms and approved by the Federal University of Uberlandia Ethics Committee (UFU), through license number 36601814.7.0000.5152 and 60374516.6.0000.5152.

\section{DEFINITIONS}

Hospital infection is acquired after the admission of the patient and it is manifested during hospitalization or after discharge, when it may be related to the hospitalization or hospital procedures (BRASIL, 1998). Inappropriate empirical therapy is the antimicrobial treatment with agents that did not have "in vitro" activity and/or treatment performed over 48 hours (DAIKOS; TSAOUSI; TZOUVELEKIS, et al. 2010). 
Hospital mortality is an evolution of patient's condition to death in 30 days after diagnosis of infection (LODISE; PATEL; KWA, et al. 2007).

\section{IDENTIFICATION OF SPECIES, ANTIMICROBIAL SUSCEPTIBILITY AND MOLECULAR TESTING}

Microbial identification and antimicrobial susceptibility testing were performed on a VITEK ${ }^{\oplus} \mathrm{II}$ automated system (bioMérieux). To assess the presence of the mecA gene, LukS gene, fnbB and clfA genes in Staphylococcus aureus strains, a polymerase chain reaction (PCR) was performed, as described previously by Kondo et al. (2007), Said Salim et al. (2005) and Tristan et al. (2003), respectively. All PCRs were carried in a mastercycler personal (Eppendorf). To perform the PCR, only $38.8 \%$ of the isolates were chosen, due to the costs of molecular techniques. The criteria for selecting these were based on the antibiogram as follows: samples with the highest resistance profiles (in the cases of groups R1 and R2) and samples only with resistance to methicillin (in the case of group R3)

\section{Statistical ANALYSis}

The evaluate of quantitative variables were performed by Student's T-Test. Categorical variables were expressed as mean and standard deviation. The statistical significance was defined by a value of $P \geq 0,05$, using the statistical program GraphPad Prism 5.01.

\section{Results AND Discussion}

Fifty-five patients (147 episodes with infection) were selected hospital-wide during surveillance period, S. aureus was the most common species (54.4\%), of which $29.9 \%$ were oxacillin resistant followed by Gram-negative bacilli (38.8\%). Most of this isolated (32.6\%) were detected from patients on the ICU. A predominance of bloodstream infection (40.9\%) among MRSA, and pneumonia (33.3\% and 31.5\%, respectively) among MSSA and Gram-negative bacilli was observed (Table 1).

Table 1- Episodes of hospital bacterial infection from November/2015 and April/2016 second according to isolation site and clinic/ sector.

\begin{tabular}{|c|c|c|c|c|c|c|}
\hline Isolation site/ Clinic & $\begin{array}{c}\text { TOTAL } \\
\mathrm{N}=147(\%)\end{array}$ & $\begin{array}{c}\text { MRSA } \\
\mathrm{N}=\mathbf{4 4}(\%)\end{array}$ & $\begin{array}{c}\text { MSSA } \\
\mathrm{N}=36(\%)\end{array}$ & p & $\begin{array}{c}\text { OTHERS GRAM- } \\
\text { POSITIVE } \\
\text { COCCI }^{1} \mathrm{~N}=10 \\
(\%)\end{array}$ & $\begin{array}{c}\text { GRAM-NEGATIVE } \\
\text { BACILLI }^{2} \\
\text { N=57(\%) }\end{array}$ \\
\hline \multicolumn{7}{|l|}{ Isolation site } \\
\hline Lung & $41(27.8)$ & $11(25.0)$ & $12(33.3)$ & 0,4126 & 0 & $18(31.5)$ \\
\hline Blood/ Catheter tip & $47(31.9)$ & $18(40.9)$ & $10(27.7)$ & 0,2473 & $8(80.0)$ & $11(19.2)$ \\
\hline Wound & $31(21.0)$ & $13(29.5)$ & $11(30.5)$ & 1,0000 & $2(20.0)$ & $5(8.7)$ \\
\hline Urine & $18(12.2)$ & $1(2.2)$ & $2(5.5)$ & 0,5855 & 0 & $15(26.3)$ \\
\hline Outhers $^{3}$ & $10(6.8)$ & $1(2.2)$ & $1(2.7)$ & 1,0000 & 0 & $8(14.0)$ \\
\hline \multicolumn{7}{|l|}{ Clinic/ Sector } \\
\hline Medical clinic & $44(29.9)$ & $22(50.0)$ & $6(16.6)$ & 0,0002 & $1(10.0)$ & $1(1.7)$ \\
\hline $\mathrm{ICU}^{5}$ & $48(32.6)$ & $11(25.0)$ & $8(22.2)$ & 0,7985 & $3(30.0)$ & $35(61.4)$ \\
\hline Cirurgical clinic & $17(11.5)$ & $7(15.9)$ & $2(5.5)$ & 0,1749 & $3(30.0)$ & $10(17.5)$ \\
\hline Others $^{6}$ & $38(25.8)$ & $4(9.0)$ & $20(55.5)$ & 0,0001 & $3(30.0)$ & $11(19.2)$ \\
\hline
\end{tabular}

\footnotetext{
${ }^{1}$ Staphylococcus haemoyticus, Staphylococcus hominis, Staphylococcuss aprophyticus, Staphylococcus epidermidis, Staphylococcus caprae, Streptococcus pyogenes, Streptococcus spp.

${ }^{2}$ Stenotrophomonas maltophilia, Serratia marcenes, Klebsiella pneumoniae, Pseudomonas aeruginosa, Acinetobacter baumannii

${ }^{3}$ Eyes, soft parts, bone

${ }^{4}$ Intensive-care unit

${ }^{5}$ Emergency room, pediatric, nursery, gynecology and obstetrics
} 


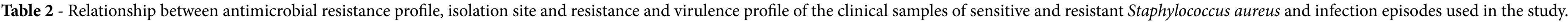

\begin{tabular}{|c|c|c|c|c|}
\hline EPISODES & RESISTANCE PROFILE & ANTIBIOTYPE & GENOTYPE (\%) & ISOLATION SITE \\
\hline \multicolumn{5}{|l|}{$\mathrm{N}=80(\%)$} \\
\hline \multirow[t]{5}{*}{$15(18.7)$} & CLI, ERY, RIF, PEN, MET & R1 & mecA+/ PVL-/ clfA-/ fnbB- (46.6) & Wound (5); Blood/ Catheter tip (2) \\
\hline & & & mecA+/ PVL-/ clfA+/ fnbB- (40.0) & Blood/ Catheter tip (3); Lung (2) \\
\hline & & & $\mathrm{NE}$ & Lung (1) \\
\hline & & & $m e c \mathrm{~A}+/ \mathrm{PVL}-/ c l f \mathrm{~A}+/$ fnbB + (6.6) & Lung (1) \\
\hline & & & mecA-/ NE/ NE/ NE (6.6) & Wound (1) \\
\hline \multirow[t]{4}{*}{$24(30.0)$} & CLI, ERY, PEN, MET & R2 & $m e c \mathrm{~A}+/ \mathrm{PVL}-/ / f f \mathrm{~A}-/$ fnbB- $(25.0)$ & Wound (3); Blood/ Catheter tip (3) \\
\hline & & & mecA+/ PVL-/ clfA+/ fnbB- (29.1) & Lung (4); Blood/ Catheter tip (2); Wound (1) \\
\hline & & & mecA-/ NE/ NE/ NE (4.1) & Bone fragment $(1)$ \\
\hline & & & $\mathrm{NE}(41.6)$ & Blood/ Catheter tip (6); Wound (2); Lung (2) \\
\hline \multirow[t]{2}{*}{$2(2.5)$} & PEN, MET & R3 & $m e c \mathrm{~A}+/ \mathrm{PVL}-/ / f f \mathrm{~A}-/$ fnbB $+(50.0)$ & Wound (1) \\
\hline & & & $\mathrm{NE}(50.0)$ & Urine (1) \\
\hline $1(1.2)$ & CLI, ERY, TET, PEN, MET & R4 & NE (100.0) & Blood/ Catheter tip (1) \\
\hline $1(1.2)$ & ERY, PEN, MET & R7 & NE (100.0) & Blood/ Catheter tip (1) \\
\hline $1(1.2)$ & CLI, ERY, MET, AMI, CIP & R8 & NE (100.0) & Lung (1) \\
\hline $11(13.7)$ & CLI, ERY, PEN & R9 & NE (100.0) & Wound (5); Blood/ Catheter tip (3); Lung (2); Eyes (1) \\
\hline $5(6.2)$ & CLI, ERY & R10 & NE (100.0) & Lung (3); Blood/ Catheter tip (1); Wound (1) \\
\hline $2(2.5)$ & ERY, PEN & R11 & NE (100.0) & Wound (1); Bone fragment (1) \\
\hline $1(1.2)$ & TET, PEN & R12 & NE $(100.0)$ & Lung (1) \\
\hline $13(16.2)$ & PEN & R13 & NE (100.0) & Blood/ Catheter tip (8); Wound (3); Lung (2); Eyes (1); Urine (1) \\
\hline $4(5.0)$ & Susceptible & $\mathrm{s}$ & NE (100.0) & Lung (2); Wound (1); Urine (1) \\
\hline
\end{tabular}

CLI, Clindamycin; ERY, Erythromycin; RIF, Rifampicin; PEN, Penicillin; MET, Meticiline; TET, Tetracycline; AMI, Amicacina; CIP, Ciprofloxacin; NE, Not evaluated

Based on the antibiotic susceptibility test, 11 antibiotypes (R1-R11) were identified among isolates of Staphylococcus aureus. The most isolated were assigned antibiotype R2 (30.0\%) and R1 (18.7\%). In R2 strains presented predominantly the genotype mecA+/ PVL-/ clfA+/ fnbB- (29.1\%), with more isolates in lung, while the R1,46.6\% strains presented the genotype mecA+/ PVL-/ clfA-/ fnbB- with more isolates in wound. (Table 2). 
The table 3 shows the risk factors for Staphylococcus aureus infections. Although only the result of avera ge age presents significance, on what patients with MRSA had a mean age of 61.1 years and with MSSA, 37.7 years, other results showed important percentage differences. The majority of patients with resistant infection had ICU hospitalization (53.8\%), made use of the inappropriate antibiotic therapy (50.0\%) and used central venous catheter (61.5\%), while the use of mechanical ventilation was higher in patients with sensitive infection (75.8\%). The average hospitalization time and the average hospitalization time until diagnostic was also higher in patients with MRSA infection (44.5 days and 25.8 days, respectively).

Table 03 - Risk factors for Staphylococcus aureus with the resistance and sensitive phenotypes of hospitalized between November/2015 and April/2016.

\begin{tabular}{|c|c|c|c|c|c|}
\hline & $\begin{array}{c}\text { TOTAL } \\
\mathrm{N}=55(\%)\end{array}$ & $\begin{array}{c}\text { MRSA } \\
\mathrm{N}=26(\%)\end{array}$ & $\begin{array}{c}\text { MSSA } \\
\mathrm{N}=29(\%)\end{array}$ & $\mathbf{p}$ & $\begin{array}{c}\text { DEATH } \\
\mathrm{N}=10^{*}(\%)\end{array}$ \\
\hline Average age, years $( \pm S D)$ & $48.8( \pm 24.46)$ & $61.1( \pm 16.56)$ & $37.7( \pm 26.24)$ & 0.0009 & 53.6 \\
\hline Average hospitalization time, days $( \pm \mathrm{SD})$ & $37.0( \pm 38.48)$ & $44.5( \pm 48.67)$ & $27.5( \pm 25.62)$ & 0.5550 & 25.0 \\
\hline $\begin{array}{l}\text { Average hospitalization time until } \\
\text { diagnostic, days }( \pm S D)\end{array}$ & $17.1( \pm 27.34)$ & $25.8( \pm 37.29)$ & $9.3( \pm 8.146)$ & 0.1785 & 16.0 \\
\hline Inappropriate antibiotic therapy & $19(34.5)$ & $13(50.0)$ & $7(24.1)$ & 0.5251 & $5(50.0)$ \\
\hline ICU hospitalization & $23(41.8)$ & $14(53.8)$ & $8(27.5)$ & 0.6610 & $8(80.0)$ \\
\hline Patients with CVC & $29(52.7)$ & $16(61.5)$ & $12(41.3)$ & 0.8193 & $9(90.0)$ \\
\hline Patients with MV & $38(69.0)$ & $16(61.5)$ & $22(75.8)$ & 0.8006 & $8(80.0)$ \\
\hline
\end{tabular}

SD, Standart deviation; ICU, Intensive-care unit; CVC, Central venous catheter; MV, Mechanical ventilation ${ }^{*} 50.0 \%$ MRSA

Analyzing and determining the importance of MRSA in research-limited countries is a great challenge, since today the study has demonstrated a more significant prevalence of Gram-negative bacilli as etiology of infections. However, our results agree with previous studies reporting a high burden of this phenotype among Staphylococcus aureus infection (ENRIGHT; ROBINSON; RANDLE, et al. 2002; WORLD HEALTH ORGANIZATION, 2015; FRIEDRICH, 2019).

Interestingly, in our assessment, MSSA was responsible for 33.3\% of pneumonia and MRSA was predominant of bloodstream infection. Special attention was given to the Gram-negative bacilli, the main cause of pneumonia and urinary tract infection. This is particularly worrisome, since the literature shows that therapeutic options are scarce or ineffective to the multidrug-resistant organisms (ZARAGOZA; ARTERO; CAMARENA, et al. 2003; BASETTI; POULAKOU; RUPPE, et al. 2017).

MRSA is a well-recognized public health problem through the world (CIMOLAI, 2007; STRUELENS, 2009; CHESSA; HANAU; MAZZARELLO, 2015). From a hospital perspective, patients with MRSA tendent to be older, to have a longer hospital stay, to have a recent background of hospitalization, among others. The present study has detected and considered such factors, in which the patients with MRSA infection were significantly older and were hospitalized 17 days longer than those with MSSA infection, as well as in previous hospitalizations when the same comparison was made.

Empirical antibiotic therapy may appear to be a good treatment strategy before the microbiological result is available, however, as an inappropriate therapy can lead to increased antibiotic resistance (ZHANG; MICEK; KOLLEF, 2015; YOON; PARK; SOHN, et al. 2016). This phenomenon is more marked in countries where the level of consumption and antimicrobial resistance are higher and where multidrug-resistant pathogens spread rapidly (CIORBA; ODONE; VERONESI, et al. 2015; BRAGA; CAMPOS; BATISTÃO, et al. 2019). In our surveillance, $50.0 \%$ of patients with MRSA infection received inappropriate antibiotic 
therapy. The literature shows that the delay in initiating appropriate therapy may lead to a higher mortality rate (WI; RHEE; KANG, et al. 2018). Due to the small number of patients, the data collected in this study did not allow the specific examination of the effect of appropriate antibiotic therapy. However, knowing the prescribing patterns of antibiotics for S. aureus infections in our institution, may justify the results of similar mortality rates between MRSA and MSSA in our cohort, which leads us to assume that empirical antibiotic therapy may have been more effective against MRSA during the study period.

$S$. aureus is also a versatile pathogen in the production of several types of virulence factors, with the objective of destroying the host cells and causing infections in different ways (FOSTER; GEOGHEGAN; GANESH, et al. 2013; OTTO, 2014; WI; RHEE; KANG, et al. 2018; JIANG; YIN; YOU, 2018). Although our sample size was small, we found important virulence factors associated with MRSA. The fnbB genes responsible for binder production of fribronectin and clfA (POWERS; WARDENBURG, 2014), responsible for cloning factor encoding were positive in $8.8 \%$ and $44.1 \%$, respectively, in MRSA strains. The lukS, responsible for the production of the PVL toxin was not present in any of the strains evaluated (MORAN; KRISHNADASAN; GORWITZ, et al. 2006), this should be found to be more prevalent in community strains.

In conclusion, although Gram-negative bacilli are predominant in nosocomial infections in Brazil, Staphylococcus aureus, particularly those resistant and more virulent, is still present in the hospital environment in important frequencies especially in ICU. Our further results confirm previous report showing a high frequency of inappropriate antibiotic therapy among MRSA associated with a very long hospitalization time.

\section{REFERENCES}

AÑÓN, R. P.; RODRÍGUEZ, R. F.; TINAJAS, A.; NANÍ, N. C.; BUSTILLO, M.; PAZ, I.; BARREIRO, R. GAYOSO DIZ, P. Estudio de sensibilidad antibiótica en las bacteriemias de un hospital secundario. Anales de Medicina Interna, v. 21, n. 10, p. 483-487, out. 2004.

BASETTI, M.; POULAKOU, G.; RUPPE, E. BOUZA, E.; SEBASTIAN, J.; VAN, H.; BRINK A. Antimicrobial resistance in the next 30 years, humankind, bugs and drugs: a visionary approach. Intensive Care Medicine, v. 43, p. 1464-1475, 21 jul. 2017.

BIMANAND, L.; TAHERIKALANI, M.; JALILIAN, F. A.; SADEGHIFARD, N.; GHAFOURIAN, S., MAHDAVI, Z.; MOHAMADI, S.; SAYEHMIRI, K.; HEMATIAN, A.; PAKZAD, I. Association between biofilm production, adhesion genes and drugs in different SCCmec types of methicillin resistant Staphyloccocus aureus strains isolated from several major hospital of Iran. Iranian Journal of Basic Medical Sciences, v. 21, n. 4, p. 400-403, abr. 2018.

BRAGA, I. A.; CAMPOS, P. A.; BATISTÃO, D.; GONTIJO FILHO, P. P.; RIBAS, R. M. Using point prevalence survey to define burden of antimicrobial use among 35 adult intensive care units in Brazil. Infectious Diseases, v. 51, n. 6, p. 459-462, mar. 2019.

BRASIL. Ministério da Saúde. Portaria Nº 2616, de 12 de maio de 1998.

CHAMBERS, H. F.; DELEO, F. R. Waves of resistance: staphylococcus aureus in the antibiotic era: Staphylococcus aureus in the antibiotic era. Nature Reviews Microbiology, v. 7, n. 9, p. 629-641, set. 2009.

CHESSA, D.; HANAU, G.; MAZZARELLO, V. An overview of Staphyloccocus epidermidis and Staphy- 
Quillici et al.

loccocus aureus with a focus on developing countries. The journal of infection in developing countries, v.9, n. 6, p. 547-550, 26 abr. 2015.

CIMOLAI, N. Methicillin-Resistant Staphylococcus aureus, Public Concern, and Legislative Mandates. Infection Control \& Hospital Epidemiology, v. 28, n. 7, p. 896-896, jul. 2007.

CIORBA, V.; ODONE, A.; VERONESI, L.; PASQUARELLA, C.; SIGNORELLI, C. Antibiotic resistance as a major public health concern: epidemiology and economic impact. Annali di igiene, v. 27, n. 3, p.56279, maio 2015.

DAIKOS, G. L.; TSAOUSI, S.; TZOUVELEKIS, L. S. ANYFANTIS I, PSICHOGIOU M, ARGYROPOULOU, A.; STEFANOU I; SYPSA V; MIRIAGOU, V.; NEPKA, M.; GEORGIADOU, S.; MARKOGIANNAKIS A, GOUKOS D; SKOUTELIS, A. Carbapenemase-Producing Klebsiella pneumoniae Bloodstream Infections: lowering mortality by antibiotic combination schemes and the role of carbapenems. Antimicrobial Agents and Chemotherapy, v. 58, n. 4, p. 2322-2328, 10 fev. 2014.

ENRIGHT, M. C.; ROBINSON, D. A.; RANDLE, G; FEIL, E.J; GRUNDMANN, H, SPRATT, B.G. The evolutionary history of methicillin-resistant Staphylococcus aureus (MRSA). Proceedings of The National Academy of Sciences, v. 99, n. 11, p. 7687-7692, 21 maio 2002.

FOSTER, T. J.; GEOGHEGAN, J. A.; GANESH, V. K.; HÖÖK, M. Adhesion Adhesion, invasion and evasion: the many functions of the surface proteins of staphylococcus aureus. Nature Reviews Microbiology, v. 12, n. 1, p. 49-62, 16 dez. 2013.

FRIEDRICH, A. W. Control of hospital acquired infections and antimicrobial resistance in Europe: the way to go. Wiener Medzinische Wochenschrift, v. 169, suppl. 1, p. 25-30, 8 jan. 2019.

HEGGERNDORNN, L. H.; GOMES, S. W.C.; SILVA, N. A; VARGES, R. G.; PÓVOA, H.C.C. Epidemiological profile and antimicrobial susceptibility of microorganisms isolated from nosocomial infections. Revista Saúde e Meio Ambiente, v. 2, n. 1, p. 26-47, 2016.

INDRAWATTANA, N.; SUNGKHACHAT, O.; SOOKRUNG, N.; CHONGSA-NGUAN, M.; TUNGTRONGCHITR, A.; VORAVUTHIKUNCHAI, S. P. ; KONG-NGOEN,T. ; KURAZONO, H. AND CHAICUMPA, W. Staphylococcus aureus Clinical Isolates: Antibiotic Susceptibility, Molecular Characteristics, and Ability to Form Biofilm. BioMed research international, v. 2013, p. 314654, 31 ago. 2013.

JIANG, B.; YIN, S.; YOU, B. Antimicrobial resistance and virulence genes profiling of methicillin-resistant Staphylococcus aureus isolates in a burn center: A 5-year study. Microbial Pathogenesis, v. 114, p. 176-179, jan. 2018.

KOECH, M.; COMO-SABETTI, K.; BOXRUDE, D. Burdens of Invasive Methicillin-Susceptible and Methicillin-Resistant Staphylococcus aureus Disease, Minesota, USA. Emerging infectious diseases, v. 25, n. 1, p. 171-174, jan. 2019.

KONDO, Y.; ITO, T.; MA, X. X. XIAO, X. M., WATANABE, S.; KREISWIRTH, B. N.; ETIENNE J. , 
HIRAMATSU, K. Combination of Multiplex PCRs for Staphylococcal Cassette Chromosome mec Type Assignment: rapid identification system for $\mathrm{mec}, \mathrm{ccr}$, and major differences in junkyard regions. Antimicrobial Agents and Chemotherapy, v. 51, n. 1, p. 264-274, 16 out. 2006.

LI, Y-Y.; LI, Q-Y.; ZHANG, X-Y; XIAO-YIN, T.; DA-PENG, C.; ZHENG-XIU, L. LODISE; T. P.; PATEL, N.; KWA, A. Current status of antibiotic therapy for Staphylococcus aureus sepsis in children. Chinese Journal of Contemporary Pediatrics, v. 21, n. 4, p. 387-392, 25 abr. 2019.

XIAO-YIN, T.; DA-PENG, C.; ZHENG-XIU, L. LODISE, T. P.; PATEL, N.; KWA, A. Predictors of 30Day Mortality among Patients with Pseudomonas aeruginosa Bloodstream Infections: impact of delayed appropriate antibiotic selection. Antimicrobial Agents and Chemotherapy, v. 51, n. 10, p. 3510-3515, 23 jul. 2007.

MORAN, G. J.; KRISHNADASAN, A.; GORWITZ, R. J; FOSHEIM, G.E, L.K; CAREY, R.B; TALAN, D. A. Methicillin-Resistant S. Aureus Infections among Patients in the Emergency Department. New England Journal Of Medicine, v. 355, n. 7, p. 666-674, 17 ago. 2006.

OLIVEIRA, G. A.; FARIA, J. B.; LEVYAND, C. E.; MAMIZUKA, M. Characterization of the Brazilian endemic clone of methicillin-resistant Staphylococcus aureus (MRSA) from hospitals throughout Brazil. Brazilian Journal of Infectious Diseases, v. 5, n. 4, p. 163-170, ago. 2001.

OTTO, M. Staphylococcus aureus toxins. Current Opinion in Microbiology, v. 17, p. 32-37, fev. 2014. PARKER, D. Humanized Mouse Models of Staphylococcus aureus Infection. Frontiers in Immunology, v. 8, p. 512, 4 maio 2017.

PAUL, M.; SHANI, V.; E, MUCHTAR; G, KARIV; E, ROBENSHTOK; L, LEIBOVICI. Systematic review and meta-analysis of the efficacy of appropriate empiric antibiotic therapy for sepsis. Antimicrobial agents and chemotherapy, n. 54, v. 11, p. 4851-63, nov. 2010.

PELEG, A. Y.; HOOPER, D. C. Hospital-Acquired Infections Due to Gram-Negative Bacteria. New England Journal of Medicine, v. 362, n. 19, p. 1804-1813, maio 2010.

POWERS, M. E.; WARDENBURG, BUBECK, J. Igniting the Fire: staphylococcus aureus virulence factors in the pathogenesis of sepsis. Plos Pathogens, v. 10, n. 2, p. 1003871, fev. 2014.

RICARDO-CALDERA, D. M.; BUELVAS-DORIA, F.; ESCOBAR-PÉREZ, J.; TOVAR, A. C. Colonización y factores de virulencia de Staphylococcus aureus resistente a meticilina en una población infantil de Montería. Iatreia, v. 28, n. 3, p. 259-268, jul. 2015.

SAID-SALIM, B.; MATHEMA, B.; BRAUGHTON; DAVIS, S., SINSIMER, D., EISNER, W., LIKHOSHVAY, Y., DELEO, F. R.; KREISWIRTH, B. N. Differential distribution and expression of Panton-Valentine leucocidin among community-acquired methicillin-resistant Staphylococcus aureus strains. Journal of clinical microbiology, v. 43, n.7, p. 3373-3379, 2005. https://doi.org/10.1128/JCM.43.7.3373-3379.2005

SANTAJIT, S.; INDRAWATTANA, N. Mechanisms of Resistance in ESKAPE Pathogens. BioMed 
research international, v. 2016, p. 2475067, 5 mai. 2016.

SCHWEIZER, M. L., EBER, M. R., LAXMINARAYAN, R., FURUNO, J. P., POPOVICH, K. J., HOTA, B., RUBIN, M. A.; PERENCEVICH, E. N. Validity of ICD-9-CM Coding for Identifying Incident Methicillin-Resistant Staphylococcus aureus (MRSA) Infections: is mrsa infection coded as a chronic disease? Infection Control \& Hospital Epidemiology, v. 32, n. 2, p. 148-154, fev. 2011.

STEFANI, S.; GOGLIO, A. Methicillin-resistant Staphylococcus aureus: related infections and antibiotic resistance. International Journal of Infectious Diseases, v. 14, p. 19-22, out. 2010.

STRUELENS, M. J. Guidelines and indicators for methicillin-resistant Staphylococcus aureus control in hospitals: toward international agreement? Current Opinion in Infectious Diseases, v. 22, n. 4, p. 337-338, ago. 2009.

TRISTAN, A.; YING, L.; BES, M. et al. Use of Multiplex PCR To Identify Staphylococcus aureus Adhesins Involved in Human Hematogenous Infections. Journal of Clinical Microbiology, v. 41, n. 9, p. 44654467, 1 set. 2003.

WEISS, S. L.; FITZGERALD, J. C.; BALAMUTH, F. et al. Delayed antimicrobial therapy increases mortality and organ dysfunction duration in pediatric sepsis. Critical care medicine, v. 42, n. 11, p. 2409-17, nov. 2014.

WI, Y. M.; RHEE, J. Y.; KANG, C. I. et al. Clinical predictors of methicillin-resistance and their impact on mortality associated with Staphylococcus aureus World Health Organization. Health care-associated infections Fact sheet. World Health Organization. 2015, v.4.

YOON, Y.K.; PARK, D. W.; SOHN, J. W. et al. Effects of inappropriate empirical antibiotic therapy on mortality in patients with healthcare-associated methicillin-resistant Staphylococcus aureus bacteremia: a propensity-matched analysis. Bmc Infectious Diseases, v. 16, n. 1, p. 331, 15 jul. 2016.

ZARAGOZA, R.; ARTERO, A.; CAMARENA, J.J. et al. The influence of inadequate empirical antimicrobial treatment on patients with bloodstream infections in an intensive care unit. Clinical Microbiology and Infection, v. 9, n. 5, p. 412-418, maio 2003.

ZHANG, D.; MICEK, S. T.; KOLLEF, M. H. Time to Appropriate Antibiotic Therapy Is an Independent Determinant of Postinfection ICU and Hospital Lengths of Stay in Patients With Sepsis. Critical care medicine, v. 43, n. 10, p. 2133-40, out. 2015. 